\title{
A Review of the Seismic Performance Size Effect of Reinforced Concrete Beams
}

\author{
Yongping Xie ${ }^{1, a}$, Jianming Guo ${ }^{2, b}$, Lei Jia ${ }^{1, c^{*}}$, Huan $Q i^{1, d}$ \\ ${ }^{1}$ College of Exploration Technology and Engineering, HeBei GEO University, Shijiazhuang \\ 050031, China \\ ${ }^{2}$ Hebei Jike Engineering Project Management CO.LTD, Shijiazhuang 050021, China \\ aaxypa@163.com, b472446445@qq.com, ${ }^{\text {c jialei1978@126.com, }{ }^{\mathrm{d}} 1226926049 @ q q . c o m}$
}

\begin{abstract}
Keywords: Reinforced Concrete Beams, Seismic Performance, Size Effect
Abstract. The size effect is defined as the reduction on the some seismic performance evaluation parameters with increasing size. As an important bearing member, the seismic performance and size effect of RC beams have been studied extensively over the past few decades, most of them came to the same conclusion, in other words, the shear bearing capacity, bending capacity and ductility of specimens decrease with the increase of section size. Therefore, for the safety of the structure, some of the country's design code have considered the size effect, but most countries have not considered the effect of size effect, which needs to be taken seriously.
\end{abstract}

\section{Introduction}

For reinforced concrete structure, reinforcement and concrete are two important building materials. With the development of high-rise buildings and large spans, the size of the components becomes larger and larger, so the requirements of components are higher and higher. At home and abroad, the size effect on mechanical properties of reinforced concrete have been extensively analyzed and studied, they found that the heterogeneity of the concrete material increased and the randomness increased when the size of the specimens increased, therefore, size effect of mechanical properties is an important characteristic of concrete materials. In addition, according to the theory of Bazant size effect, the size effect of concrete is mainly caused by fracture of crack, some factors, such as the diameter and spacing of reinforcement, may affect the size effect of concrete materials. Therefore, the mechanical properties of reinforced concrete structure can be influenced by the size effect of the concrete material itself, and the size effect of the component may exist. As an important bearing member, the seismic performance and size effect of RC beams have been studied extensively over the past few decades.

\section{Study on shear size effect of reinforced concrete beams}

Lots of research results show that the size effect on shear stress of reinforced concrete beam without stirrups is obvious, namely shear stress decreases with increasing member section height when component occurs shear failure, and the stirrup ratio and longitudinal reinforcement ratio have an important influence on the size effect of shear bearing capacity.

\section{Research status in other countries}

Knai[1] found that the average shear strength of the cross section was reduced by about $40 \%$ when the cross section height $\mathrm{h}$ increased from $200 \mathrm{~mm}$ to $800 \mathrm{~mm}$, and the safety coefficient decreased with the increase of section height when the cross section height increased from $500 \mathrm{~mm}$ to $1200 \mathrm{~mm}$, Yu. L [2] found that section shear strength reduce about $40.7 \%$ and the section size on shear strength of beams without stirrup is obvious, and which conclusion has also been Collins [3, 4]. Bogdan and Podgorniak [5] tested the shear capacity of reinforced concrete beams, the section height ranged from $125 \mathrm{~mm}$ to $1000 \mathrm{~mm}$ and the concrete strength ranged from $40 \mathrm{MPa}$ to $100 \mathrm{MPa}$, the results show that the strength of concrete for the improvement of shear bearing capacity of reinforced concrete beam was not very obvious, but the shear bearing capacity reduced with the increase of the section size. K H Yang[6] tested the shear bearing capacity of deep beams, the section height ranged from $300 \mathrm{~mm}$ to $1800 \mathrm{~mm}$, 
the results show that the influence of section size on shear bearing capacity is obvious, and size effect on bearing capacity of beams with large shear-span ratio was more obvious than the specimens with small shear-spa ratio. Ghannoum[7] found that the nominal shear stress was reduced by more than 50\% when the section height ranged from $90 \mathrm{~mm}$ to $960 \mathrm{~mm}$, and proposed a calculation formula of shear bearing capacity, as shown in Eq(1). In addition, Bazant[8] et al. studied the size effect on bearing capacity of nearly 300 reinforced concrete beams without stirrup, and obtained the formula of the size effect of longitudinal reinforcement ratio and shear span ratio. Walraven [9] found that the failure modes of specimens was different when shear-span ratio was different, but the size effect was similar, and the bearing capacity of beams decreased with the increase of the cross section height, stirrup may decrease but it cannot fundamentally eliminate the size effect of bearing capacity.

$$
V_{c}=\frac{215.8}{100+d} \sqrt{f_{c}^{\prime}} b_{w} d
$$

\section{Research status in China}

Shunbo Zhao and Guofan Zhao[10] tested the steel fiber concrete beams without stirrup to study the size effect of shear bearing capacity, the results show that there is a significant size effect on the bearing capacity of the oblique section when the cross-section height is greater than 300mm. Fenglan Li [11] also found that the shear bearing capacity of the reinforced concrete beam has the size effect, and decreases with the increase of the cross-section height. Xiuli du [12] tested the 5 groups of reinforced concrete beams under low reversed cyclic loading, the cross-section ranged from $80 \mathrm{~mm} \times 200 \mathrm{~mm}$ to $400 \mathrm{~mm} \times 1000 \mathrm{~mm}$, and then the seismic performance of beams was analyzed, including the hysteretic characteristics, bearing capacity, ductility and energy dissipation et.al, the results show that the size effect of seismic performance is obvious besides energy dissipation, and the nominal shear stress and shear bearing capacity reserve coefficient decrease with cross-section height increase.

\section{Study on bending size effect of reinforced concrete beams}

For cross sectional flexural performance of reinforced concrete beam, most of the existing theory think bending damage of beam caused by longitudinal reinforcement tensile yield, size effect mainly comes from the strength of concrete and the cohesive force between reinforcement and concrete, so the size effect on the bending capacity of cross section is not obvious, Howerer, the experimental results of these conclusions are mostly based on the results of small size specimen test. In recent years, some large size specimens were tested, the results show that the bending capacity of cross-section has ovbious size effect.

\section{Research status in other countries}

Research of reinforced concrete beam bending failure is mainly manifested in two aspects, one is the size effect on bearing capacity of compressive concrete in the middle of the beams, and the second is the size on the deformation capacity of reinforced concrete beams. In 2000, two different sizes of reinforced concrete beams under the four-point loading were tested and were calculated by finite element method by Ozbol [13], the length, width and height of the first specimen are $3600 \mathrm{~mm}, 200 \mathrm{~mm}$, $100 \mathrm{~mm}$ respectively, the length, width and height of the second specimen were $7200 \mathrm{~mm}, 400 \mathrm{~mm}$, $200 \mathrm{~mm}$ respectively, the shear-span ratio is equal to 7.5 , and there were no stirrups, and the reinforcement ratio of the tensile reinforcement was $7.3 \%$, the results show that the size effect of strength is no obvious, but the large size specimen is more brittle after the peak loading, namely, size effect of ductility is obvious. In 2008, Belgin [14] tested four groups of overreinforced concrete beams without stirrups, the reinforcement ratio of the tensile reinforcement was $3 \%$, the specimens were designed according to similar, the results show that the size effect of bending strength is obvious, and the size effect of the two dimensional similar beams is more obvious. In order to study the size effect of bending of reinforced concrete beams, Alca [15] tested 12 reinforced concrete beam subjected to four-point loading, there was no stirrups and compression steel bars, and the tensile reinforcement ratio is appropriate, the grade of concrete was $50 \mathrm{MPa}$ and $90 \mathrm{MPa}$, three kinds of cross sectional dimensions were $150 \mathrm{~mm} \times 230 \mathrm{~mm}, 235 \mathrm{~mm} \times 360 \mathrm{~mm}, 335 \mathrm{~mm} \times 515 \mathrm{~mm}$, respectively, however, the results show 
that the bending deformation and bearing capacity of reinforced concrete beams have no obvious size effect. Appa et al. [16] designed three different scales of reinforced concrete beams, width and height and length of specimens were $50 \mathrm{~mm} \times 100 \mathrm{~mm} \times 500 \mathrm{~mm}, 100 \mathrm{~mm} \times 200 \mathrm{~mm} \times 1000 \mathrm{~mm}, 200 \mathrm{~mm} \times 400 \mathrm{~mm}$ $\times 2000 \mathrm{~mm}$, respectively, the ratio of the four kinds of tensile reinforcement ratio were designed and was $0.15 \%, 0.3 \%, 0.6 \%$ and $1.0 \%$, respectively, the grade of concrete was $37 \mathrm{MPa}$, so 12 beams under four-point loading were tested, the results show that there are obvious size effect on the bending behavior of reinforced concrete beams, and the ductility decreases with increases of specimen size when the cross sectional height of beam exceeds 200mm. Seong Tae Yi[17] tested the mechanical properties and deformation properties of simply supported reinforced concrete beams without stirrups and compression steel bars, the four-point loading method is adopted, the section height of specimens were $200 \mathrm{~mm}, 350 \mathrm{~mm}$ and $600 \mathrm{~mm}$, respectively, the grade of concrete was $37 \mathrm{MPa}$, shear-span ratio was equal to 3.0. the results show that the mechanical properties of the specimens show the obvious size effect, the bending strength decreases with the height of the beam, and the compressive strain of the compression zone decreases with the size of the specimen. Bigaj[18] tested the bending failure properties of reinforced concrete beams longitudinal tensile reinforcement without compression longitudinal, the four-point loading method is adopted, single point loading method in the middle of span was adopted, the cross sectional size of specimens tested was $50 \mathrm{~mm} \times 120 \mathrm{~mm}, 100 \mathrm{~mm} \times 210 \mathrm{~mm}$, $250 \mathrm{~mm} \times 490 \mathrm{~mm}$, respectively, shear-span ratio was 5.5, there are two kinds of tensile reinforcement ratio, $0.28 \%$ and $1.12 \%$ respectively, it is found that the rotational capacity of the plastic hinge region has obvious size effect. Ma. Richie J[19] studied the size effect on structural performance of reinforced concrete beams under flexure, the $\operatorname{size}(\mathrm{b} \times \mathrm{h} \times \mathrm{l})$ of specimens was $37.5 \mathrm{~mm} \times 75 \mathrm{~mm} \times 675 \mathrm{~mm}$, $75 \mathrm{~mm} \times 150 \mathrm{~mm} \times 1350 \mathrm{~mm}, 150 \mathrm{~mm} \times 300 \mathrm{~mm} \times 2700 \mathrm{~mm}, 300 \mathrm{~mm} \times 600 \mathrm{~mm} \times 5400 \mathrm{~mm}$, there are four kinds of arrangement of longitudinal and stirrup, One was that there is neither stirrup nor tension longitudinal bar, one was the only tension longitudinal bar that is not stirrup, and the other two were both stirrups and tension longitudinal bar, the results show that, for almost all series, the ratio of the maximum load and the yield load $\mathrm{Pu} / \mathrm{Py}$ decreases with increase of dimension of specimen, and the ductility decreases as the increase of the specimen size.

\section{Research status in China}

Xinfeng Zheng[20] studied the size effect on bending performance and seismic performance of high strength concrete beams subjected to monotonic loading and reversed cyclic loading, and Zhixin Chen[21] studied the size effect on bending performance and seismic performance of normal strength concrete beams subjected to monotonic loading and reversed cyclic loading, they all came to the same conclusion, and the conclusion is as follows: (1) there is no obvious size effect on cracking load, yield load and ultimate load, (2) reinforced concrete beams have better ductility and rotational capacity of plastic hinge, and the size effect is obvious, (3) the size change has no obvious effect on the stiffness degradation of the specimen; (4) there is no obvious size effect of the plastic hinge length, and its length is about equal to $1 \mathrm{~h}_{0}$; (5) the energy dissipation capacity shows obvious size effect and decreases with the increase of section size. Hongyu Zhou [22] studied the size effect on seismic performance of 28 reinforced concrete beams, the cross sectional height ranged from $200 \mathrm{~mm}$ to $1000 \mathrm{~mm}$, the main conclusions are as follows: (1) the strength and deformation capacity of concrete decreases with the increase of the section size, which has a negative effect on the flexural capacity of the component, (2) with the increase of section size, factors such as steel reinforcement and internal force arm have a positive effect on flexural capacity, (3) equivalent plastic hinge length is approximately equal to $1 \mathrm{~h} 0$, and the process of plastic hinge has obvious size effect., the plastic hinge of small size specimen appears early and increase with the increase of the section size, (4) the measured pressure strain at the root of the specimen decreases with the increase of section size. 


\section{The application of size effect in design Code}

Some countries in the concrete structure design code considered the influence of size effect on the ultimate bearing capacity of RC beams, such as, Concrete structure design code in China GB 50010-2010 section 6.3.3[23], for the normal bending member without stirrup and bend-up bars, its inclined section bearing capacity shall meet the following requirements:

$$
\begin{aligned}
V & \leq V_{\mathrm{c}}=0.7 \beta_{\mathrm{h}} f_{\mathrm{t}} b h_{0} \\
\beta_{\mathrm{h}} & =\left(800 / h_{0}\right)^{1 / 4}
\end{aligned}
$$

European code EN-1992-1-1:2004 section 6.2.2[24], for member not requiring design shear reinforcement, the design value for the shear resistance VRd,c is given by:

$$
V_{\mathrm{Rd}, \mathrm{c}}=\left[C_{\mathrm{Rd}, \mathrm{c}} k\left(100 \rho_{l} f_{\mathrm{ck}}\right)^{1 / 3}+k_{\mathrm{l}} \sigma_{\mathrm{cp}}\right] b_{\mathrm{w}} d
$$

Where

$$
k=1+\sqrt{200 / d} \leq 2.0
$$

Code of practice for design and construction in British BS 8110-1:1997(2002) section 3.4.5.6[25], The value of $\mathrm{Vc}$ design concrete shear stress is derived from the expression:

$$
V_{\mathrm{c}}=0.79\left\{100 A_{\mathrm{s}} /\left(b_{\mathrm{v}} d\right)\right\}^{1 / 3}(400 / d)^{1 / 4} / \gamma_{\mathrm{m}}
$$

\section{Conclusions}

The size effect is an increasing concern of scholars all over the world. A large number of studies have shown that the influence of section size on shear bearing capacity of beams is obvious, especially if the stirrup ratio is small or without the stirrup, the size effect is more obvious, and the bending strength decreases with the height of the beam, and the compressive strain of the compression zone decreases with the size of the specimen. Therefore, in the structure design, if the conclusions based on the small size specimen are applied in the large size specimen, the security of the structure or component is necessarily reduced.

\section{Acknowledgements}

This work was supported by the National Natural Science Foundation of China (No.51408378) and the Hebei Province Natural Science Foundation (No. E2015403018).

\section{References}

[1] Kani G N J.How safe are our large reinforced concrete beams ACI Journal, 64(3):138 141(1967).

[2] Yu L, Yi C. Shear behavior of large reinforced concrete beams without web reinforcement[J]. Advances in Structural Engineering,16(4):653-666(2013).

[3] Collins M P and Kuchma D K. How safe are our large lightly reinforced beams,slabs and footing[J].ACI Structural Journal, 96(4):482-490(1999).

[4] Angelakos D, Bentz E C and Collins M P. Effect of concrete strength and minimum stirrups on shear strength large members[J].ACI Structural Journal,98(3):290-300(2001).

[5] Bogdan A, Podgorniak Stanik. The influence of concrete strength, distribution of longitudinal reinforcement, amount of transverse reinforcement and member size on shear strength of reinforced concrete members [D]. Department of Civil Engineering Unibersity of Toronto, (1998).

[6] Keun Hyeok Yang,Heon Soo Chung,Eun Taik Lee,HeeChang Eun, Shear characteristics of high-strength concrete deep beams without shear reinforcement[J].Engineering Structures, 25:1343-1352(2003). 
[7] Wassim M.Ghannoum, size effect on shear strength of reinforced concrete beams [D]. Department of Civil Engineering of Applied Mechanics Mcgill Unibersity, Montreal,Canada,(1998).

[8] Bazant,Jin-Keun Kim.size effect in shear failure of longitudinally reinforced beams[J].ACI journal,9-10,81:456-468(1984).

[9] Walraven J,Lehwalter N. Size effect in short beams loaded in shear[J]. ACI Structural Journal,91(5):585 593(1994).

[10] Shunbo Zhao, Guofan Zhao, Chengkui Huang. Size effect of steel fiber reinforced concrete without web reinforcement under shear [J]. Journal of North China Institute of Water Conservancy and Hydroelectric Power, 18(2):7-12(1997).

[11]Fenglan Li, Fang Li, Jielan Yang, Shear bearing capacity of reinforced concrete beams without web reinforcement under concentrated load [J]. Journal of North China Institute of Water Conservancy and Hydroelectric Power,18(3):23-27(1997).

[12]Xiuli Du, Jian Yuan, Hongyu Zhou, Jianwei Zhang, Zhenbao Li. The experimental study of size effect on shear capacity of reinforced concrete beam under low cyclic loading [J]. Journal of earthquake engineering and engineering vibration,31(5):31-38(2011).

[13]J.Ozbolt,D.Mestrovic,Y.-J.Li and R.Eligehausen. Compression failure of beams made of different concrete types and sizes[J].Journal of structural Engineering,126(2):200-209(2000).

[14]Cagatay M.Belgin,Siddik Sener.Size effect on failure of overreinforced concrete beams[J].Engineering Fracture Mechanics,75:2308-2319(2008).

[15] Nedim Alca,Scott D.B. Alexander, and James G.Macgregor.Effect of size on flexural behavior of high-strength concrete beams[J].ACI Structural Journal,94(1):59-67(1997).

[16] G.Appa Tao,I.Vifayanand. Studies on ductility of RC beams in flexure and size effect[J] Fracture Mechanics of Concrete and Concrete Struetures,2:671-675(2007).

[17] Seong-Tae Yi,Min-Su Kim,Jin-Keun Kim,Jang-Ho Jay Kim.Effect of specimen size on flexural compressive strength of reinforced concrete members[J]. Cement and Concrete Composites, 29:230-240(2007).

[18]Bigaj A J, Walraven J C. Size effects in plastic hinges of reinforced concrete members [J].HERON, 47(1):53-75(2002).

[19] Ma. Richie J, CAIBAL, Yoshiyuki IWASHITA, et.al. Size effect on structural performance of reinforced concrete beams under flexure. J.Struct. Constr. Eng, AIJ,73(626):625-632(2008).

[20] Xinfeng Zheng. Experimental study on size effect on flexural behaviour of high -strength concrete beams [D].Dalian University of Technology, (2011).

[21]Zhixin Chen. Experimental study on size effect on flexural behaviour of reinforced concrete beams [D]. Dalian University of Technology, (2012).

[22] Hongyu Zhou. Test study on size effect of flexural behaviour of RC flexural members [D] Beijing University of Technology, (2012).

[23] Ministry of Construction of the People's Republic of China. GB 50010-2010 Code for design of concrete structures. Beijing: China Architecture \& Building Press:(2010).

[24]BS EN 1992-1-1:2004 Euro code 2: Design of concrete structures-Part 1-1:General rules and rules for buildings [S]. European Committee for Standardization, BSI publication, (1993).

[25]BS 8110-1:1997, British Standard, Structural use of concrete-Part 1:Code of practice for design and construction [S]. Technical Committee B/525. 30 32(2002). 